\title{
Bioactivity of Glomerular Ultrafiltrate During Heavy Proteinuria May Contribute to Renal Tubulo-Interstitial Lesions \\ Evidence for a Role for Insulin-like Growth Factor I
}

Raimund Hirschberg

Division of Nephrology \& Hypertension, Harbor-UCLA Medical Center, Torrance, California 90509

\begin{abstract}
Clinical and experimental data have indicated that heavy proteinuria in renal glomerular diseases is associated with the formation of tubulo-interstitial fibrosis and contributes to the progression of renal failure. Albumin in glomerular ultrafiltrate does not appear to cause this sequelae, rather than compounds that are associated with ultrafiltered plasma proteins. One such protein-bound factor could be insulin-like growth factor I (IGF-I). The present studies show that in nephrotic rats, IGF-I is ultrafiltered in conjunction with IGF-binding protein-2 and is present in proximal tubular fluid at $1.35 \mathrm{nM}$. Proximal tubular fluid from nephrotic rats autophosphorylates IGF-I receptors in cultured proximal tubular cells. Nephrotic, but not control, rat proximal tubular fluid increases the $\left[{ }^{3} \mathrm{H}\right]$ thymidine incorporation in cultured tubular cells, and neutralizing IGF-I-receptor antibodies partially inhibit this activity. Incubation of cultured proximal tubular cells with an extract that was prepared from nephrotic rat urine increases the secretion of collagen types I and IV. Secretion of the two collagens is in part ameliorated by neutralizing IGF-I-receptor antibody. In concert, these findings suggest that the IGF-I present in nephrotic rat tubular fluid is bioactive and may contribute to the development of tubulo-interstitial fibrosis in chronic nephrotic glomerular diseases. (J. Clin. Invest. 1996. 97: 116-124.) Key words: insulin-like growth factor I • insulinlike growth factor-binding proteins - glomerular ultrafiltrate $\bullet$ interstitial fibrosis $\bullet$ nephrotic syndrome
\end{abstract}

\section{Introduction}

Several investigators have suggested that the glomerular ultrafiltration of plasma proteins or factors that are associated with serum proteins may cause or contribute to the development of tubulo-interstitial pathology, which accounts for much of the progressive renal failure in nephrotic kidney diseases (1-3). Insulin-like growth factor I (IGF-I) is bound to specific serum proteins and patients or rats with the nephrotic syndrome ex-

Address correspondence to Raimund Hirschberg, Box 406, HarborUCLA Medical Center, 1000 West Carson Street, Torrance, CA 90509. Phone: 310-222-3891; FAX: 310-782-1837; E-mail: hirschberg@ afp76.humc.edu or hirschb@ix.netcom.com

Received for publication 14 December 1995 and in revised form 6 April 1996.

J. Clin. Invest.

(C) The American Society for Clinical Investigation, Inc.

0021-9738/96/07/116/09 \$2.00

Volume 98, Number 1, July 1996, 116-124 crete the peptide with urine at greatly increased rates (4-6). IGF-I is a growth factor peptide $(7,600 \mathrm{D})$ that has metabolic functions and autocrine, paracrine, and endocrinelike modes of action (7). These actions include a rise in procollagen mRNAs and secretion of collagen proteins in mesangial cells (8). IGF-I could also have similar effects on proximal tubular cells, which are known to secrete collagens and other extracellular matrix proteins (9). IGF-I has mitogenic activity in cultured glomerular mesangial as well as proximal tubular cells and in renal proximal tubules in intact rats $(8,10,11)$. IGF-I receptors are expressed in the nephron in the apical as well as the basolateral membrane of proximal tubules $(12,13)$, and biologic action of recombinant human IGF-I (rhIGF-I) ${ }^{1}$ through both proximal tubule cell membranes has been demonstrated $(13,14)$.

IGF-I binds with high affinity to IGF-binding protein (IGFBP)-3 when the latter is associated with another protein, the acid labile subunit $(\sim 85 \mathrm{kD})$, to form a complex of $\sim 150$ $\mathrm{kD}$. In fact, $\sim 75 \%$ of IGF-I in serum is normally present in this high molecular weight form $(15,16)$. Most of the remaining IGF-I is present in serum bound to IGFBP-1, -2 , or -4 in a molecular complex of $\sim 45 \mathrm{kD}$, and only $<1 \%$ of the circulating peptide is present in the free form (17).

In the nephrotic syndrome, a defect in the integrity of the glomerular capillary wall results in the ultrafiltration of plasma proteins that leads to heavy proteinuria. We and other investigators have previously shown that the serum levels of IGF-I and IGFBP-3 in the nephrotic syndrome are reduced, but IGFBP-2 levels are elevated due to a severalfold increase in the liver synthesis (4).

Studies were performed to test the hypothesis that, in rats with the nephrotic syndrome, IGF-I is ultrafiltered in glomeruli, and proximal tubular fluid activates tubular cell IGF-I receptors, increases the thymidine incorporation, and raises the secretion of collagen type I and IV, possibly through its IGF-I content. By this means, nephrotic glomerular ultrafiltrate could contribute to tubular changes that are associated with glomerular diseases.

\section{Methods}

In vivo studies

The nephrotic syndrome was induced in male Munich Wistar rats (200-250 g body wt; Simonson, Gilroy, CA) with a single intravenous injection of Doxorubicin- $\mathrm{HCl}$ (Adriamycin; Cetus Corp., Emeryville, CA), $4 \mathrm{mg} / \mathrm{kg}$. Adriamycin has been shown to induce a minimalchange diseaselike glomerular lesion in rats that is associated with heavy proteinuria, hypoalbuminemia, and hypercholesterolemia (18). These findings are comparable with the more clearly defined ne-

1. Abbreviations used in this paper: IGFBP, IGF-binding protein; rhIGF-I, recombinant human IGF-I; SNGFR, single nephron GFR. 
phrotic syndrome in humans, and this term will be used for the rat model in this study. Control rats received saline. Stable gross proteinuria developed at $\sim 3 \mathrm{wk}$ after the injection and most studies were performed in rats at 18 to $21 \mathrm{~d}$ after the adriamycin injection. Individual studies included measurements of parameters describing the single nephron glomerular filtration of water and small solutes, of albumin and $\mathrm{IgG}$, and of IGF-I and associated IGFBPs. Furthermore, proximal tubule fluid was collected for the study of IGF-I receptor activation (autophosphorylation) and $\left[{ }^{3} \mathrm{H}\right]$ thymidine incorporation in cultured proximal tubule cells. Finally, the stimulation of collagen secretion by IGF-I that is present in nephrotic urinary extracts was examined in cultured proximal tubule cells.

Renal and glomerular hemodynamics. The glomerular ultrafiltration rate (GFR) and the single nephron glomerular filtration rate of water and small solutes were measured in nephrotic and control rats at $3 \mathrm{wk}$ using micropuncture methods as previously described (19-21). Briefly, rats were anesthetized with intraperitoneal Inactin (BykGulden, Konstanz/Bodensee, FRG), $120 \mathrm{mg} / \mathrm{kg}$ body wt. A tracheostomy was performed and PE-50 catheters were inserted into the left internal jugular vein, left femoral artery, and the left ureter. The kidney was sealed in cotton soaked in $1 \%$ agar solution and was bathed continuously with saline at $37^{\circ} \mathrm{C}$.

An infusion of $\left[{ }^{3} \mathrm{H}\right]$ inulin (ICN Radiochemicals Div., ICN Biomedicals Inc., Irvine, CA) in Ringer's solution at $100 \mu \mathrm{Ci} / \mathrm{ml}$ was given continuously at $1.5 \mathrm{ml} / \mathrm{h}$. In some studies (vide infra) inulin was omitted. Surgical plasma losses were substituted (19). Arterial blood pressure was measured continuously with a pressure transducer (P23dB; Gould-Statham Inc., Cleveland, $\mathrm{OH}$ ) that was connected to the femoral artery catheter and recorded with a multichannel recorder (8805C; Hewlett-Packard Co., Waltham, MA). Measurements of hydrostatic pressures in glomerular capillaries, Bowman's space, and proximal tubules were made as previously described (19). Exactly timed fluid collections were made from early proximal tubules that were accessible with sharpened 9-11- $\mu$ m-tip glass pipettes filled with Sudan black-stained mineral oil, and an oil drop was injected at the beginning of each collection to prevent downstream escape of tubule fluid during the collection. Early proximal tubule segments were defined as those followed by at least two further surface loops and were identified by injection of a small amount of brilliant greenstained Ringer's saline with a sharpened 3- $\mu \mathrm{m}$-tip pipette. For the measurement of the single nephron GFR (SNGFR), five 3-min tubule fluid collections were obtained. For other individual protocols, more extensive, exactly timed tubule fluid collections were made as described below.

An arterial blood sample was obtained at the beginning and end of the period of micropuncture to measure the serum ${ }^{3} \mathrm{H}$-insulin, total protein, and albumin levels. In rats in which nephron hemodynamics were measured, 2 to 3 collections of efferent arteriolar blood were made from star vessels with sharpened $\sim 13-\mu \mathrm{m}$-tip glass pipettes (19). Individual determinants of nephron ultrafiltration were measured or calculated as described before (19).

Measurements of the single nephron ultrafiltration of IGF-I, albumin, and $\operatorname{IgG}$. An additional six control and eight nephrotic rats were prepared for tubule micropuncture as described above. These animals, however, received initial infusions of saline without inulin to collect early proximal tubule fluid for IGF-I measurements. From each animal, tubule fluid was collected with oil-filled $9-11-\mu \mathrm{m}$ sharpened pipettes. Several collections for up to $10 \mathrm{~min}$ each were obtained in each animal and pooled in $200 \mu \mathrm{l}$ of $0.5 \mathrm{~N} \mathrm{HCl}$. Samples were stored at $-70^{\circ} \mathrm{C}$ for subsequent IGF-I assay. During these micropuncture measurements, urine was collected from the left ureter for measurement of IGF-I.

In the nephrotic rats, after completion of these collections, the infusion was exchanged for Ringer's saline containing $\left[{ }^{3} \mathrm{H}\right]$ inulin and $1 \mathrm{~h}$ was allowed for equilibration of the inulin into extracellular spaces. During the period of equilibration, timed tubule fluid collections (5-8 min) were made and urine was collected from the left kidney to determine the albumin $(\sim 68 \mathrm{kD})$ and $\operatorname{IgG}(\sim 158 \mathrm{kD})$ ultrafiltration and excretion rates and to calculate fractional clearances. The timed collections were pipetted into $450 \mu \mathrm{l}$ of sample buffer $(1 \%$ normal rabbit serum in PBS) and stored at $-20^{\circ} \mathrm{C}$ until assayed for albumin and IgG. After equilibration, timed 3-min proximal tubule fluid collections were obtained and urine was collected to determine the SNGFR and GFR. In a pilot study, the single nephron-sieving coefficient for albumin was estimated in 17 nephrotic animals at different periods of time (5-22 d) after the injection of adriamycin. In the latter animals, the single nephron ultrafiltration rate of albumin and the SNGFR were measured concomitantly.

Examination of the single nephron ultrafiltration of IGFBPs. To examine the glomerular ultrafiltration of IGFBPs, early proximal tubule fluid was obtained from 12 rats at $3 \mathrm{wk}$ after the induction of the nephrotic syndrome. In each of these animals, individual collections of early proximal tubule fluid were made for a total of $\sim 100$ min, and samples that were obtained from three consecutive rats were pooled and stored in $15 \mu \mathrm{l}$ of $2 \times$ SDS sample buffer $(0.15 \mathrm{M}$ Tris- $\mathrm{HCl}, \mathrm{pH} 6.8,4 \%$ SDS, $40 \%$ glycerol, and $0.05 \%$ bromphenol blue) for subsequent Western ligand and immune analysis.

Proximal tubular fluid collections for ex vivo studies. Additional collections of proximal tubular fluid were made from nephrotic and control rats and combined in separate pools. Aliquots of pooled proximal tubular fluid were used in in vitro experiments (see below) to examine the activation of IGF-I receptors and the $\left[{ }^{3} \mathrm{H}\right]$ thymidine incorporation in cultured proximal tubular cells.

\section{Laboratory assays}

Total protein was measured in urine that was collected from the left ureter during the micropuncture studies. Proteins were precipitated by addition of trichloroacetic acid at a final concentration of $10 \%$. Precipitates were pelleted by centrifugation $\left(5,000 \mathrm{~g}, 10 \mathrm{~min}, 4^{\circ} \mathrm{C}\right)$ and dissolved in $1 \mathrm{M} \mathrm{NaOH}$. The total protein concentration was then measured with the Lowry protein assay using bovine serum albumin as standard. Serum total protein was measured with the Lowry assay and albumin was measured in diluted serum with an ELISA (19).

Albumin and IgG in glomerular ultrafiltrate that was collected by micropuncture was measured by the respective specific ELISA. The albumin ELISA has been described previously in detail from this laboratory (19).

The IgG ELISA was adopted from a method which was previously developed in this laboratory to measure low levels of $\mathrm{IgG}$ in normal human urine (22). Briefly, 96-well flat-bottom polystyrene ELISA plates (Corning Glass Works, Corning, NY) were coated with goat anti-rat IgG (Cappel Laboratories, Organon Teknika Corp, West Chester, PA), $5 \mu \mathrm{g} / \mathrm{ml}$, in coating buffer $\left(0.1 \mathrm{M} \mathrm{Na}_{2} \mathrm{HCO}_{3}, \mathrm{pH}\right.$ 9.8), $100 \mu \mathrm{l} /$ well, and incubated at $4^{\circ} \mathrm{C}$ for $72 \mathrm{~h}$. Wells were washed $3 \times$ with washing buffer $\left(0.15 \mathrm{M} \mathrm{NaCl}, 0.02 \mathrm{M} \mathrm{NaH}_{2} \mathrm{PO}_{4}, \mathrm{pH} 7.3\right.$, $0.05 \%$ Tween 20). Standards (rat IgG, Cappel Laboratories; 0.5 to 20 $\mathrm{ng} / \mathrm{ml}$ ), or diluted samples in incubation buffer (PBS containing $1 \%$ normal rabbit serum) or blanks (100 $\mu \mathrm{l} /$ well), were incubated overnight at room temperature. Wells were washed $3 \times$ and then incubated with second antibody (horseradish peroxidase-labeled rabbit anti-rat IgG, Cappel Laboratories) at 1:7,500 in incubation buffer, $100 \mu \mathrm{l} /$ well, for $1 \mathrm{~h}$ at room temperature. Plates were washed $5 \times$ and substrate solution $(0.2 \mathrm{M}$ Tris- $\mathrm{HCl}, 0.15 \mathrm{M} \mathrm{NaCl}, \mathrm{pH} 6.0,0.25 \%$ $o$-phenylene diamine, $0.012 \% \mathrm{H}_{2} \mathrm{O}_{2}$ ), $100 \mu \mathrm{l} /$ well, was added and plates were incubated for 30-60 $\mathrm{min}$ in the dark at room temperature until a green color developed. The reaction was stopped by addition of $0.1 \mathrm{M}$ sodium sulfite in $4 \mathrm{M} \mathrm{H}_{2} \mathrm{SO}_{4}, 50 \mu \mathrm{l} /$ well. The absorbance was measured at $492 \mathrm{~nm}$ in a microplate reader (UV-Max; Molecular Devices Corp., Menlo Park, CA). The intra- and interassay coefficient of variation are both $<5 \%$.

IGF-I levels in proximal tubule fluid were estimated after extraction and semipurification of samples by nonequilibrium radioimmunoassay using minor modifications of a previously described method $(20,23,24)$. Briefly, IGF-I was extracted and separated by reversephase HPLC on a methanol gradient with a mobile phase of $7 \%(\mathrm{vol} /$ vol) acetic acid using a C-18 peptide HPLC-column (Vydac, Hisperia, 
CA) at a total flow rate of $1.0 \mathrm{ml} / \mathrm{min}$ and 1 -min fractions were collected. The IGF-I fractions (as determined by calibration with ${ }^{125} \mathrm{I}$ IGF-I) were pooled, evaporated in a Speed-Vac concentrator (Savant Instruments, Inc., Farmingdale, NY) and taken up in $25 \mu \mathrm{l}$ of assay buffer $\left(0.03 \mathrm{M} \mathrm{NaH}_{2} \mathrm{PO}_{4}, 0.01 \mathrm{M}\right.$ Na-EDTA, pH 7.5, 0.02\% protamine sulfate, $0.02 \%$ Na-azide, $0.05 \%$ Tween 20 ). Recombinant human IGF-I (gift from Ciba Geigy, Summit, NY) were used as standards that were analyzed in quadruplicate. Samples were preincubated with primary antibody UB3-189 (provided as a gift by the National Hormone and Pituitary Program through Ogden BioServices Corp., Rockville, MD) for $72 \mathrm{~h}$ at $4^{\circ} \mathrm{C}$. ${ }^{125} \mathrm{I}$-IGF-I (Amersham Corp., Arlington Heights, IL), 10,000 cpm/tube, was added and tubes were incubated for another $24 \mathrm{~h}$ at $4^{\circ} \mathrm{C}$. Sheep anti-rabbit IgG (Cappel Laboratories) was added at a final dilution of 1:100 and tubes were incubated for $2 \mathrm{~h}$ at room temperature. Subsequently, normal rabbit serum (Cappel Laboratories) was added at a final dilution of 1:100 and tubes were incubated at room temperature for $2 \mathrm{~h}$. Immune complexes were pelleted and washed twice with $4 \%$ polyethylene glycol in $0.15 \mathrm{M} \mathrm{NaCl}, \mathrm{pH}$ 7.2. Supernatants were decanted and the radioactivity in the pellet was measured in a gamma counter. The recovery after extraction and HPLC-separation, tested with ${ }^{125}$ I-IGF-I spiked, diluted serum, was $80 \pm 2 \%$. The intra- and interassay coefficients of variation for the RIA were $8.1 \pm 0.9 \%(n=7)$ and $14.3 \pm 1.6 \%(n=5)$, respectively.

Analysis of IGFBPs in proximal tubular fluid. IGFBPs were analyzed by Western ligand blot as well as Western immunoblot as previously described by Hossenlopp et al. $(25,26)$ as well as from this laboratory (4). Briefly, proximal tubular fluid in sample buffer was denatured by incubating in a water bath at $90^{\circ} \mathrm{C}$ for $10 \mathrm{~min}$ and then electrophoresed in $12 \%$ SDS-polyacrylamide minigels. Separated proteins were electrotransferred onto nitrocellulose membranes. Filters were blocked with blocking buffer ( $20 \mathrm{mM}$ Tris, $\mathrm{pH}$ 7.4, $50 \mathrm{mM}$ $\mathrm{NaCl}, 1 \% \mathrm{BSA}$ ) for $1 \mathrm{~h}$ at room temperature. Membranes were then incubated with ${ }^{125}$ I-IGF-I, $1 \mu \mathrm{Ci}$ in $12 \mathrm{ml}$ of blocking buffer containing $0.05 \%$ Tween 20 for $16 \mathrm{~h}$ at $4^{\circ} \mathrm{C}$. Membranes were then washed extensively with washing buffer $(20 \mathrm{mM}$ Tris, $\mathrm{pH} 7.4,50 \mathrm{mM} \mathrm{NaCl}$, $0.05 \%$ Tween 20 ), dried at $4^{\circ} \mathrm{C}$, and autoradiographed.

Western immunoblotting was performed for IGFBP-2 on the same membrane after completion of the ligand blotting assay without prior stripping. The membrane was briefly washed in washing buffer, reblocked with blocking buffer containing 3\% fat-free dry milk instead of BSA, and incubated for $16 \mathrm{~h}$ with rabbit anti-bovine IGFBP-2 polyclonal antibody (Upstate Biotechnology Inc., Lake Placid, NY), $1: 1,500$ in $20 \mathrm{ml}$ of blocking buffer at $4^{\circ} \mathrm{C}$. This antibody reacts well with rat IGFBP-2 (4). Membranes were washed extensively and incubated successively with biotinylated anti-rabbit $\operatorname{IgG}(1: 3,000$, Bio-Rad Laboratories, Hercules, CA) and horseradish peroxidase-streptavidin, 1:3,000 (Southern Biotechnology Associates, Birmingham, AL) both in blocking buffer containing $5 \%$ dry milk and $0.1 \%$ Tween 20 . After extensive washing, bands were visualized with enhanced chemiluminescence using a commercially available reagent and the manufacturer's instructions (Amersham Corp.).

\section{In vitro studies}

Mouse proximal tubular cells were kindly donated by Carolyn Kelly, M.D., La Jolla, CA. These cells had been obtained from microdissected mouse proximal tubules (9). Cells were grown in DMEM/F-12 (1:1) containing $10 \% \mathrm{FCS}, 50 \mathrm{nM}$ hydrocortisone, penicillin $200 \mathrm{IU} /$ $\mathrm{ml}$, and Streptomycin, $200 \mu \mathrm{g} / \mathrm{ml}$. In the present studies, the cells were used in three lines of experiments to examine: $(a)$ whether IGF-I in proximal tubular fluid from nephrotic rats activates IGF-I receptors; $(b)$ whether proximal tubular fluid raises the tubule cell thymidine incorporation through IGF-I receptor mechanisms; and (c) whether an IGF-I-containing acidic urinary extract increases the secretion of collagen proteins by cultured proximal tubule cells.

Examination of IGF-I receptor activation by nephrotic tubular fluid. Cultured mouse proximal tubule cells were washed $3 \times$ with serum-free medium and incubated for $24 \mathrm{~h}$ in medium containing
BSA, $50 \mu \mathrm{g} / \mathrm{ml}$, in lieu of FCS. Cells were then detached by trypsination and washed $3 \times$ with phosphate-free MEM (Gibco Laboratories, Life Technologies Inc., Grand Island, NY). The cellular ATP-pool was metabolically labeled by incubating the cell suspension with MEM containing [ ${ }^{32} \mathrm{P}$ ] orthophosphoric acid, $1 \mathrm{mCi} / \mathrm{ml}$ (DuPontNEN, Boston, MA), in a shaking water bath at $37^{\circ} \mathrm{C}$ for $1.5 \mathrm{~h}$. Cells were washed and resuspended in $1 \mathrm{ml}$ of P-free MEM. Equal aliquots of suspended cells were quickly added to microcentrifuge tubes containing either no additive (control), pooled proximal tubule fluid from nephrotic rats at a final dilution of 1:13 (estimated final IGF-I concentration of $\sim 100 \mathrm{pM})$, rhIGF-I $(100 \mathrm{pM})$, or rhIGF-I together with recombinant human IGFBP-2 (Austral Biologicals, San Ramon, CA) at 100 and $500 \mathrm{pM}$, respectively. Incubations were performed for $2 \mathrm{~min}$ at room temperature. Cells were then quickly pelleted by centrifugation for $15 \mathrm{~s}$ at $8,000 \mathrm{~g}$. Supernatants were aspirated, cells were washed $3 \times$ with ice-cold MEM and then lysed in $1.0 \mathrm{ml}$ of lysate buffer $\left(60 \mathrm{mM} \mathrm{Na}_{2} \mathrm{HPO}_{4}, 20 \mathrm{mM} \mathrm{NaH}_{2} \mathrm{PO}_{4}, 60 \mathrm{mM} \mathrm{NaCl}, \mathrm{pH} 7.4,1 \%\right.$ Triton $\mathrm{X}-100,0.1 \%$ sodium dodecyl sulfate, $0.5 \%$ sodium deoxycholate, $2 \mathrm{mM} \mathrm{Na}_{3} \mathrm{VO}_{4}, 0.2 \mathrm{mM}$ leupeptin, $0.2 \mathrm{mM}$ pepstatin $\mathrm{A}, 0.2 \mathrm{mM}$ aminobenzene-sulfonylfluoride, $15 \mathrm{mM}$ sodium azide, and $1 \mu \mathrm{g} / \mathrm{ml}$ aprotinin) by repeated freezing in liquid $\mathrm{N}_{2}$ and thawing on ice. Lysates were precleared by centrifugation at $14,000 \mathrm{~g}$ for $45 \mathrm{~min}$ and cleared by incubation with $50 \mu$ protein- $\mathrm{A} / \mathrm{G}_{\text {Plus }}$-agarose (Oncogene Science Inc., Uniondale, NY) for $1 \mathrm{~h}$ at $4^{\circ} \mathrm{C}$ on a shaking platform and subsequent centrifugation. Supernatants were incubated with monoclonal anti-IGF-I receptor antibody (Oncogene Science Inc.), $1.5 \mu \mathrm{g} /$ $\mathrm{ml}$, and $25 \mu \mathrm{l}$ of protein- $\mathrm{A} / \mathrm{G}_{\text {Plus }}$-agarose suspension at $4^{\circ} \mathrm{C}$ for $16 \mathrm{~h}$ on a shaking platform. Immune complexes were pelleted by centrifugation and washed $5 \times$ with ice-cold lysate buffer. The final pellet was taken up in $2 \times$ SDS-sample buffer containing $100 \mathrm{mM}$ dithiothreitol. Samples were denatured by boiling for $3 \mathrm{~min}$ and electophoresed in a $7.5 \%$ SDS-PAGE gel by loading each complete sample in a single lane. The gel was dried and autoradiographed. The activity of nephrotic rat proximal tubular fluid to activate tubular cell IGF-I receptors was examined in three separate but similar experiments.

Measurement of the effect of early proximal tubular fluid on $\left[{ }^{3} \mathrm{H}\right]$ thymidine incorporation in cultured mouse proximal tubular cells. Mouse proximal tubule cells were grown to about $70 \%$ confluence in 96-well flat-bottom culture plates (Corning Glass Works). Cells were washed $3 \times$, and then incubated with DMEM/F-12 containing BSA $(25 \mu \mathrm{g} / \mathrm{ml}), 100 \mu \mathrm{l} /$ well for $24 \mathrm{~h}$. Cells were washed again and incubated with DMEM/F-12, $50 \mu \mathrm{l} /$ well, containing $\left[{ }^{3} \mathrm{H}\right]$ thymidine $(30$ $\mu \mathrm{Ci} / \mathrm{ml})$ and geometrically diluted rhIGF-I, 4.9 to $5000 \mathrm{pM}(n=4$ each), or nephrotic rat proximal tubule fluid (1:13) in the presence $(n=2)$ or absence $(n=2)$ of neutralizing anti-IGF-I-receptor monoclonal antibody $(10 \mu \mathrm{g} / \mathrm{ml})$ or normal rat proximal tubule fluid $(1: 13$, $n=2$ ). Incubations were made for $5 \mathrm{~h}$ at $37^{\circ} \mathrm{C}$ in a cell incubator. Wells were washed $4 \times$ in ice-cold medium, $2 \times$ with $5 \%$ trichloroacetic acid, $2 \times$ with $95 \%$ ethanol, and then dried in a fume hood. Cells were lysed overnight with $1 \mathrm{~N} \mathrm{NaOH}, 25 \mu \mathrm{l} /$ well. The ${ }^{3} \mathrm{H}$-labeled radioactivity was measured in a liquid scintillation counter. Total cell protein per well was measured with a microadaptation of the Lowry assay in separate wells in the same microplate.

In a separate experiment, cells were incubated in 96-well plates with medium $(25 \mu \mathrm{l} /$ well $)$ containing $\left[{ }^{3} \mathrm{H}\right]$ thymidine $(40 \mu \mathrm{Ci} / \mathrm{ml})$, and either normal or nephrotic rat proximal tubular fluid at a dilution of 1:10 or rhIGF-I ( $200 \mathrm{pM}$ and $1 \mathrm{nM})$, each in the presence or absence of IGF-I-receptor neutralizing $\mathrm{mAb}(n=7$ per group). Cells were incubated for $8 \mathrm{~h}$ at $37^{\circ} \mathrm{C}$ in a humidified atmosphere. The incorporated tritium radioactivity was measured as above. The total cell protein per well was measured in separate wells $(n=24)$ and was $15.4 \pm 0.6$ $\mu \mathrm{g} / \mathrm{well}$.

Measurement of the effect of a urinary extract on secretion of collagen type I and IV in mouse proximal tubular cells. Bladder urine that was collected and pooled from control or nephrotic rats was sterile filtered and dialyzed for $48 \mathrm{~h}$ at $4^{\circ} \mathrm{C}$ against 6 liters of $50 \mathrm{mM}$ acetic acid in deionized, distilled water using dialysis membrane tubing with a molecular cutoff of $500 \mathrm{D}$ (Spectrum, Laguna Hills, CA). The dialy- 


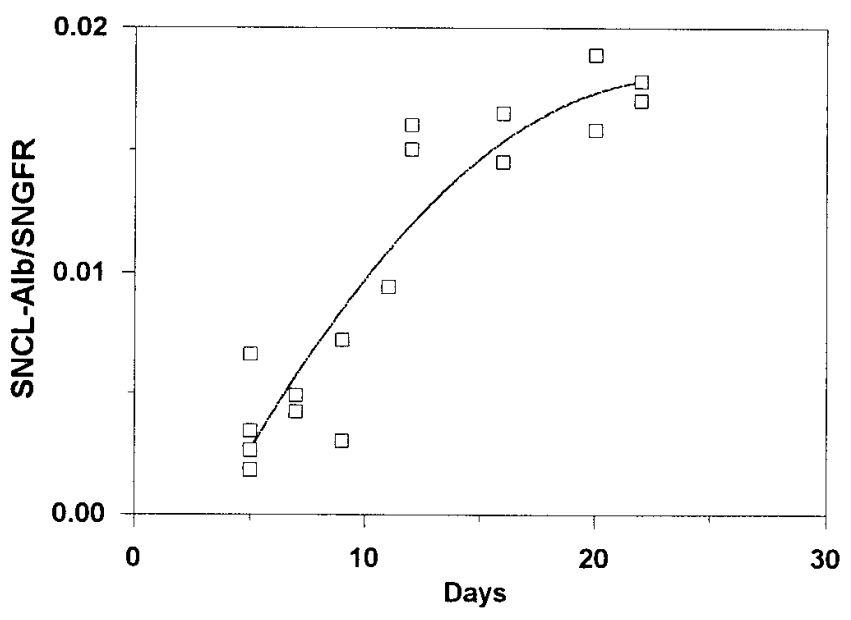

Figure 1. Single nephron sieving coefficient for albumin in nephrotic rats. The sieving coefficient was calculated from the single nephron clearance of albumin and the SNGFR that were measured between 5 and $22 \mathrm{~d}$ after administration of adriamycin. The figure demonstrates a progressive increase in the sieving coefficient, particularly during the initial $14 \mathrm{~d}$, which then tends to level off. SNCL-Alb, single nephron clearance of albumin.

sate was exchanged at $12-\mathrm{h}$ intervals. The dialyzed urine was centrifuged through spin concentrators (molecular cutoff at $30 \mathrm{kD}$; Amicon Corp., Danvers, MA) and the flow-through was lyophilized. The lyophysate was resolved in DMEM/F-12 corresponding to the original urine volume. The IGF-I concentration in the nephrotic urine extract was estimated by RIA and was $41 \mathrm{ng} / \mathrm{ml}$.

Mouse proximal tubular cells were grown to $\sim 75 \%$ confluence in 6-well plates and incubated in DMEM/F-12 containing BSA, $50 \mu \mathrm{g} /$ $\mathrm{ml}$, in lieu of FCS for $24 \mathrm{~h}$. Cells were incubated for $60 \mathrm{~h}$ at $37^{\circ} \mathrm{C}$ with medium ( $2 \mathrm{ml} /$ well) containing no additive (control), rhIGF-I ( $2 \mathrm{nM})$, nephrotic urinary extract at 1:5, or nephrotic urinary extract (1:5) plus IGF-I-receptor monoclonal antibody, $5 \mu \mathrm{g} / \mathrm{ml}(n=12 \mathrm{each})$. In a separate experiment, cells were incubated without additive (control), or with rhIGF-I $(2 \mathrm{nM})$, IGF-I-receptor antibody $(5 \mu \mathrm{g} / \mathrm{ml})$, or rhIGF-I $(2 \mathrm{nM})+$ IGF-I-receptor antibody $(5 \mu \mathrm{g} / \mathrm{ml})$. Conditioned media were cleared by centrifugation and concentrated with spin concentrators with a cutoff of $30 \mathrm{kD}$. Concentrates were taken up in coating buffer to a final volume of $200 \mu \mathrm{l}$ (10-fold concentrated). Collagen type I and IV were measured in duplicate with specific ELISA assays using the methods that were published previously from this laboratory (8). Cells were lysed in $1 \mathrm{~N} \mathrm{NaOH}$ and the total cell protein was measured with the Lowry protein assay.

Statistical comparisons were made with Student's $t$ test or the Kolmogorov-Smirnov Test using Statmost software (Data Most Corp., Salt Lake City, UT). Results are reported as means \pm SEM. Significance was defined as $P<0.05$.

\section{Results}

A single intravenous injection of adriamycin, $4 \mathrm{mg} / \mathrm{kg}$, induced proteinuria, primarily albuminuria. Adriamycin altered the single nephron-sieving coefficient for albumin, which increased progressively, particularly during the first $2 \mathrm{wk}$ (Fig. 1). All studies were performed at 18-21 d after the administration of adriamycin.

Glomerular hemodynamics. At $3 \mathrm{wk}$ in nephrotic rats there was a trend, albeit not significant, for reduced GFR, single nephron GFR, and single nephron plasma flow compared to control animals (Table I). However, the glomerular transcapillary pressure gradient was significantly lower and the glomerular ultrafiltration coefficient tended to be lower in the nephrotic compared to the control rats (Table I).

Nephron ultrafiltration of proteins and IGF-I at 3 wk in nephrotic rats. The serum albumin levels were significantly reduced in nephrotic rats $(1.8 \pm 0.2 \mathrm{~g} / \mathrm{dl})$ compared to controls $(2.9 \pm 0.2 \mathrm{~g} / \mathrm{dl}, P<0.05)$, and the total serum protein concentrations were 4.2 vs $5.9 \mathrm{~g} / \mathrm{dl}$, respectively $(P<0.05)$. The proteinuria from the left kidney was $9 \pm 2 \mu \mathrm{g} / \mathrm{min}$ and $216 \pm 32 \mu \mathrm{g} /$ min in control and nephrotic rats, respectively. As was reported previously (4), the serum IGF-I levels were significantly reduced in the nephrotic rats $(203 \pm 43 \mathrm{ng} / \mathrm{ml})$ compared to control animals $(320 \pm 29 \mathrm{ng} / \mathrm{ml}, P<0.05)$ and IGF-I was excreted in urine in nephrotic animals at a rate of $129 \pm 10 \mathrm{pg} / \mathrm{min}$ $(0.61 \pm 0.15 \mathrm{pg} / \mu \mathrm{g}$ urinary protein).

The glomerular ultrafiltration rates of albumin, $\mathrm{IgG}$, and IGF-I were estimated at $3 \mathrm{wk}$ in nephrotic rats. The glomerular ultrafiltration of albumin was much greater than that of IgG (Table II), whereas the serum albumin levels $(1.8 \pm 0.2 \mathrm{~g} / \mathrm{dl})$ were only about threefold greater than the serum IgG levels $(0.6 \pm 0.1 \mathrm{~g} / \mathrm{dl})$, suggesting selectivity towards albumin ultrafiltration.

In four out of six normal control rats, the proximal tubular fluid IGF-I levels were at or below the sensitivity of the IGF-I assay. In two control rats, the $\mathrm{B} / \mathrm{B}_{0}$ values for these two samples were at the low end of the RIA-displacement curve (Fig. 2 ) where the assay does not reliably discriminate. Thus, in normal control rats, the single nephron glomerular ultrafiltration of IGF-I is extremely low. In contrast, proximal tubule fluid IGF-I levels could be estimated in all nephrotic rats (Fig. 2, Table II). The molar concentration of IGF-I in early proximal tubular fluid in nephrotic rats was calculated from the average SNGFR and the nephron filtration rate of IGF-I and averaged $1.35 \mathrm{nM}$ (Table II).

From the primary data, the fractional single nephron clearance (sieving coefficient) for IGF-I could be calculated and was $\sim 5 \%$ (Table II). Moreover, the ratio of the single nephron

Table I. Renal and Glomerular Dynamics at 3 wk in Control and Nephrotic Rats

\begin{tabular}{|c|c|c|c|c|c|c|c|c|c|}
\hline & & BW & MAP & $\mathrm{GFR}_{\mathrm{L}}$ & SNGFR & SNPF & SNFF & $\Delta \mathrm{P}$ & LpA \\
\hline & $n$ & gram & $m m H g$ & $\mathrm{ml} / \mathrm{min}$ & $n l / \min$ & $\mathrm{nl} / \mathrm{min}$ & & $m m H g$ & $\mathrm{nl} / \mathrm{s}$ per $\mathrm{mmHg}$ \\
\hline Control rats & 6 & $225 \pm 5$ & $108 \pm 3$ & $0.90 \pm 0.10$ & $38 \pm 2$ & $135 \pm 11$ & $0.28 \pm 0.01$ & $37 \pm 2$ & $0.062 \pm 0.008$ \\
\hline Nephrotic rats & 6 & $216 \pm 9$ & $112 \pm 3$ & $0.75 \pm 0.12$ & $36 \pm 3$ & $113 \pm 11$ & $0.32 \pm 0.03$ & $33 \pm 1 *$ & $0.035 \pm 0.010$ \\
\hline
\end{tabular}

$* P<0.05$. BW, body weight; MAP, mean arterial blood pressure; GFR $\mathrm{L}_{\mathrm{L}}$, glomerular filtration rate of the left kidney; SNPF, single nephron plasma flow; SNFF, single nephron filtration fraction; $\Delta \mathrm{P}$, glomerular transcapillary hydrostatic pressure difference; LpA, glomerular ultrafiltration coefficient. 
Table II. Single Nephron Ultrafiltration of Proteins and IGF-I at 3 wk in Nephrotic Rats

\begin{tabular}{lc}
\hline Albumin & $14 \pm 2 \mathrm{ng} / \mathrm{min}$ \\
IgG & $0.6 \pm 0.2 \mathrm{ng} / \mathrm{min}$ \\
IGF-I (Ultrafiltration) & $376 \pm 49 \mathrm{fg} / \mathrm{min}$ \\
IGF-I (UF per SNGFR) & $10.2 \pm 0.8 \mathrm{fg} / \mathrm{nl}$ \\
IGF-I (in Prox Tub Fluid) & $1.35 \pm 0.1 \mathrm{nM}$ \\
SNCL $_{\text {IGF-I }} /$ SNGFR* $^{*}$ & $0.052 \pm 0.006$ \\
SNCL $_{\text {IGF-I }} /$ SNCL $_{\text {Albumin }}{ }^{\ddagger}$ & $3.17 \pm 1.06$
\end{tabular}

SNCL, single nephron clearance; *fractional single nephron clearance (sieving coefficient) of IGF-I; " ${ }^{\star}$ ratio of single nephron clearance of IGF-I and Albumin; UF, Ultrafiltration. Data are mean \pm SEM.

clearances of IGF-I and albumin was on average 3.17 (range $1.17 \pm 7.87$ ) and was $>1.0$ in all nephrotic rats (Table II). The fractional excretion of IGF-I by the left kidney (renal clearance of IGF-I divided by the GFR) was $1.28 \times 10^{-3} \pm 0.35 \times 10^{-3}$.

IGF-binding proteins in glomerular ultrafiltrate. The difference in the proximal tubular levels of IGF-I between control and nephrotic rats suggested that IGF-I underwent glomerular ultrafiltration as a complex with IGFBPs. Thus, IGFBPs were examined in early proximal tubular fluid by Western ligand blot and Western immunoblot. Western ligand blotting demonstrated a single band at $\sim 33 \mathrm{kD}$ in each of the pooled samples, consistent with the presence of IGFBP-2 in nephrotic rat proximal tubular fluid (Fig. $3 A$ ). No bands were visualized that may correspond to IGFBP-1, -3 , or -4 (Fig. $3 A$ ). The same membrane shown in Fig. $3 A$ was subsequently analyzed by Western immunoblotting with a specific anti-IGFBP-2 antibody. This analysis demonstrates that the single band found in the Western ligand blot is indeed IGFBP-2 (Fig. 3 B). This latter assay also depicts a band slightly above the $100-\mathrm{kD}$ marker, which is an unidentified protein that may cross-react in the assay. This band does not correspond to any of the known IGFbinding proteins.

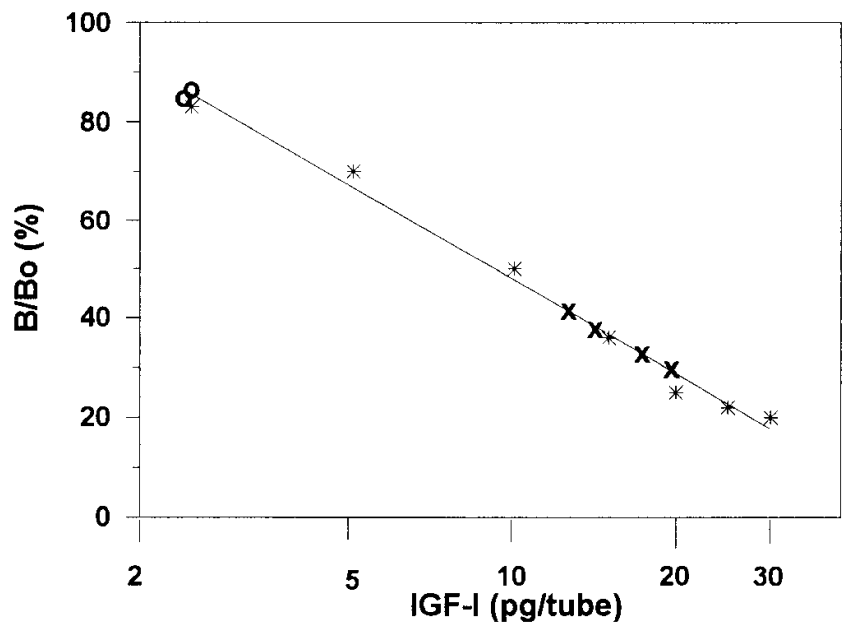

Figure 2. Semilogarithmic displacement curve of an IGF-I radioimmunoassay. $\mathrm{B} / \mathrm{B}_{0}$ as a percentage of the zero standard. $*$, rhIGF-I standards (mean of quadruplicates); $\bigcirc$, values in pooled early proximal tubular fluid from normal control rats; and X, IGF-I levels in pooled early proximal tubular fluid from nephrotic rats.

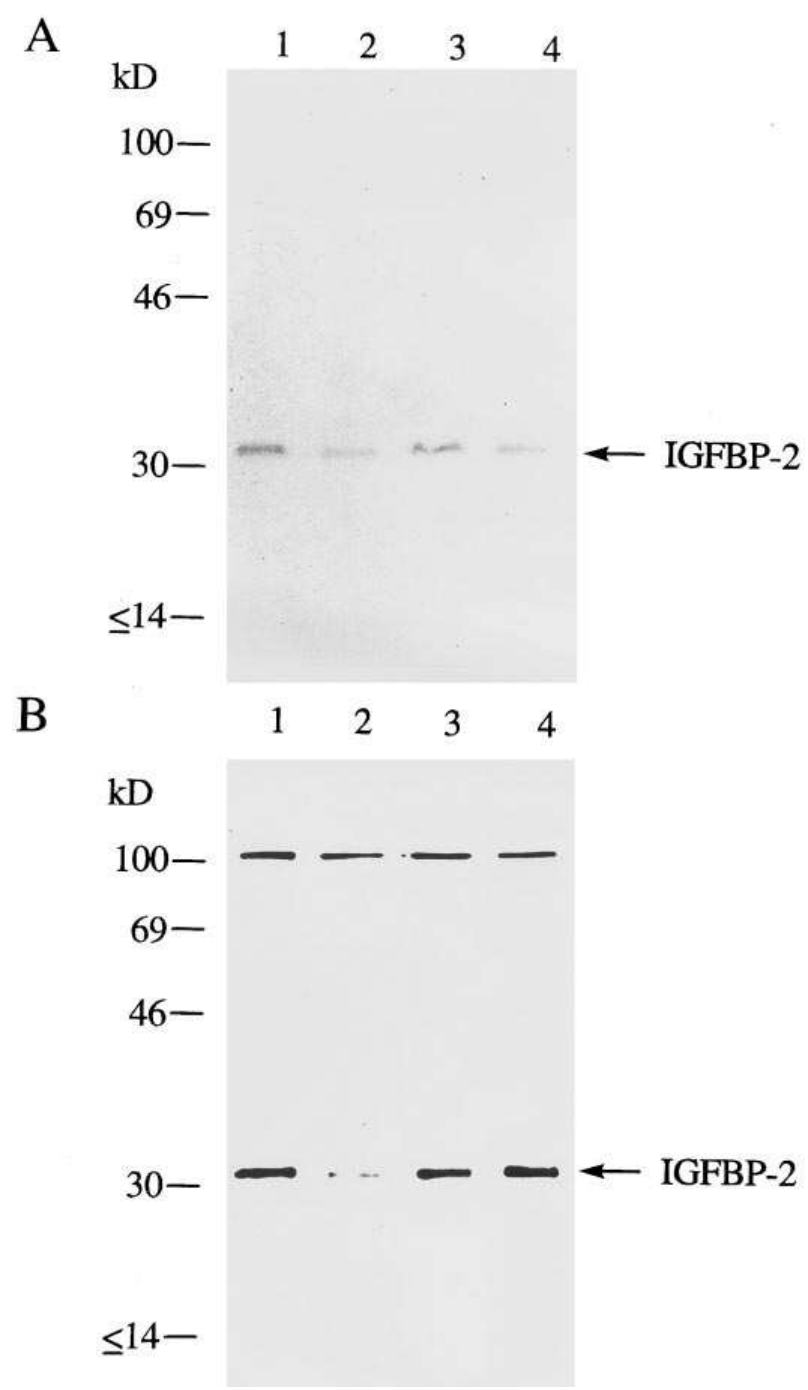

Figure 3. Analysis of IGF-binding proteins in proximal tubular fluid collections from nephrotic rats. Each lane contains pooled tubule fluid from three nephrotic rats. $(A)$ Western ligand blot demonstrates the presence of a single band in each lane at $\sim 33 \mathrm{kD}$ corresponding to IGFBP-2. (B) Western immunoblot with specific antiIGFBP-2 antibody of the same nitrocellulose membrane as in $(A)$ after completion of the Western ligand analysis. The immunoblot confirms that the band at $\sim 33 \mathrm{kD}$ is IGFBP-2. A second band is visualized at $\sim 110 \mathrm{kD}$ that depicts an unidentified protein that crossreacts with the primary or secondary antibody. Its molecular mass does not correspond to any of the known binding proteins and this band is not visible in the ligand blot $(A)$.

Thus, the only IGF-binding protein that can be demonstrated in glomerular ultrafiltrate in nephrotic rats is IGFBP-2, suggesting that the only or primary mode of glomerular ultrafiltration of IGF-I is the filtration of molecular complexes containing IGFBP-2 and IGF-I.

IGF-I-receptor activation by proximal tubular fluid was examined in vitro using cultured mouse proximal tubular cells that were metabolically labeled with phosphorous-32. Fig. 4 depicts an autoradiogram of immune-precipitated IGF-I receptors after separation by SDS-PAGE under reducing conditions. In all four lanes, a band is visualized at $\sim 95 \mathrm{kD}$ corresponding to the IGF-I receptor $\beta$-subunit. In three separate 


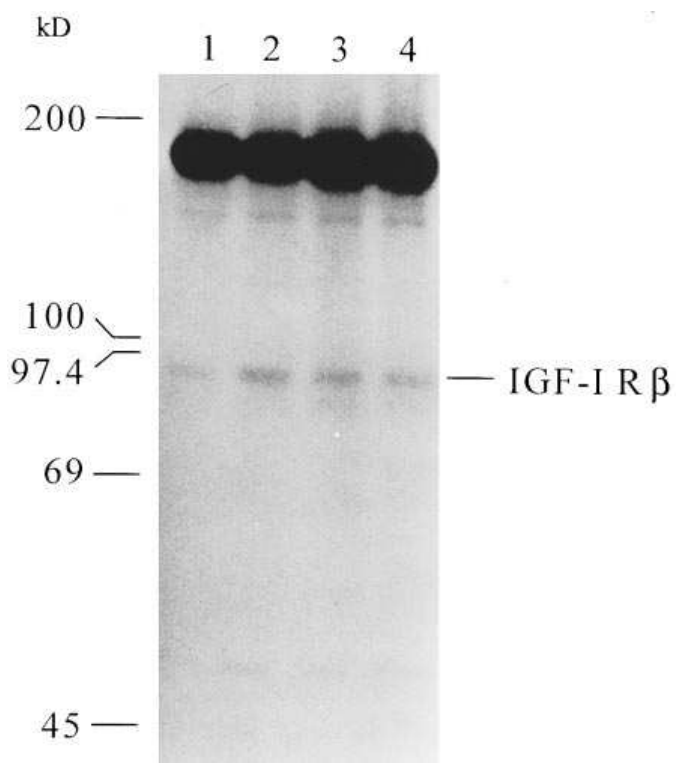

Figure 4. Activation of IGF-I receptors by nephrotic rat proximal tubule fluid. Mouse proximal tubular cells were metabolically labeled with phosphorous-32. Equal aliquots of suspended cells were then incubated ( $2 \mathrm{~min}$ ) without additive (control, lane 1 ), pooled nephrotic rat proximal tubule fluid at 1:13 (corresponding to an estimated final IGF-I concentration of $\sim 100 \mathrm{pM}$ ) (lane 2), rhIGF-I (100 pM, lane 3 ), and rhIGF-I $(100 \mathrm{pM})+$ rhIGFBP-2 (500 pM, lane 4). Cells were lysed and IGF-I receptors were immunoprecipitated and electrophoresed under reducing conditions in a 7.5\% SDS-polyacrylamide gel. The autoradiogram depicts the phosphorylated $\beta$-subunit of the receptor at $\sim 95 \mathrm{kD}$ as indicated $(I G F-I R \beta)$. The heavily phosphorylated band on top of each lane corresponds to an unidentified coprecipitated protein.

experiments, nephrotic proximal tubular fluid tended to increase the IGF-I receptor $\beta$-subunit phosphorylation 1.9 \pm 0.4 -fold compared to control. rhIGF-I and rhIGF-I + IGFBP-2 increased the receptor autophosphorylation $2.3 \pm 0.4-$ and $1.6 \pm 0.3$-fold, respectively.

Effects of glomerular ultrafiltrate on $\left[{ }^{3} H\right]$ thymidine incorporation by cultured proximal tubular cells. Incubation of mouse proximal tubular cells with rhIGF-I at concentrations between 4.9 and 5,000 pM progressively increased the $\left[{ }^{3} \mathrm{H}\right]$ thymidine uptake by the cells (Fig. 5). There was a log-linear correlation $(r=0.88)$ between the $\left[{ }^{3} \mathrm{H}\right]$ thymidine incorporation and the rhIGF-I concentration (Fig. 5). Fig. 5 also suggests that nephrotic rat proximal tubular fluid increases the $\left[{ }^{3} \mathrm{H}\right]$ thymidine incorporation. In the presence of IGF-I-receptor neutralizing antibody, the $\left[{ }^{3} \mathrm{H}\right]$ thymidine uptake was less, and both samples obtained from normal control rats resulted in an even lesser rate of incorporation of $\left[{ }^{3} \mathrm{H}\right]$ thymidine in cultured proximal tubule cells (Fig. 5). These semiquantitative findings were confirmed in a similar experiment using equal aliquots from a single pool of normal or nephrotic proximal tubular fluid. The results of this latter experiment are shown in Table III. rhIGF-I, as well as nephrotic rat proximal tubular fluid, increased the $\left[{ }^{3} \mathrm{H}\right]$ thymidine uptake significantly above control $(P<0.05)$. The neutralizing IGF-I receptor antibody reduced the IGF-Iinduced increase in thymidine uptake $(P<0.05$, Table III), tended to reduce the nephrotic tubular fluid-induced uptake of $\left[{ }^{3} \mathrm{H}\right]$ thymidine $(P=0.0692)$, but did not significantly alter the uptake of the tracer under control conditions (Table III).

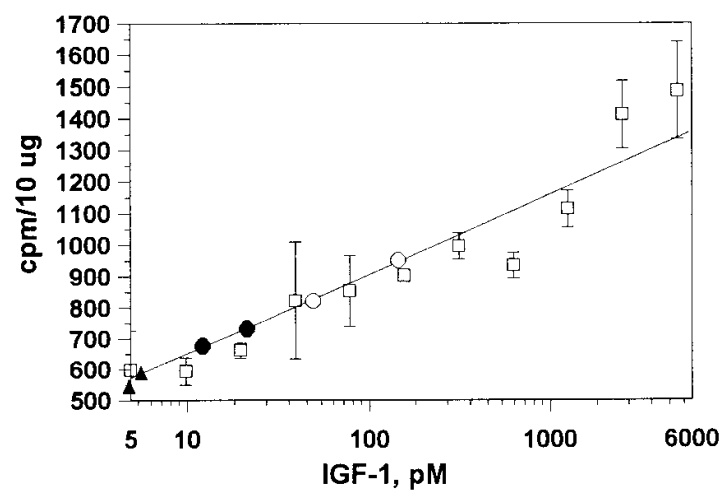

Figure 5. Effects of IGF-I and proximal tubular fluid on $\left[{ }^{3} \mathrm{H}\right]$ thymidine incorporation in cultured proximal tubular cells. Cells were incubated with DMEM/F-12 containing $\left[{ }^{3} \mathrm{H}\right]$ thymidine with addition of rhIGF-I between 4.9 and 5,000 $\mathrm{pM}(\square, n=4$, each). The regression line ( $r=$ $0.88)$ is shown. Note that the IGF-I concentrations are depicted logarithmically. The $\left[{ }^{3} \mathrm{H}\right]$ thymidine-incorporation activities of diluted nephrotic rat tubular fluid in the absence $(\mathrm{O}$, two samples) or presence $(\boldsymbol{\bullet}$, two samples) of IGF-I-receptor neutralizing antibody, and of two diluted samples of normal tubular fluid $(\mathbf{A})$ are plotted on the regression line.

Effects of IGF-I and urinary extracts on collagen type I and $I V$ secretion by cultured proximal tubule cells. As previously shown by other investigators, cultured mouse proximal tubule cells secrete both collagen type I and IV, as well as other extracellular matrix proteins (9). Incubation of the cells with rhIGF-I, $2 \mathrm{nM}$, for $60 \mathrm{~h}$ significantly increased the secreted amounts of collagen type I $(P<0.05)$ and type IV $(P<0.05)$ (Fig. 6). Similarly, the levels of both collagen proteins in medium were increased when the cells were incubated with the extract from nephrotic rat urine (Fig. 6). Addition of an IGF-I-receptor neutralizing antibody reduced the rise in collagen secretion that was induced by the urine extract (Fig. 6). As determined in a separate experiment, the IGF-I-receptor neutralizing antibody alone did not affect the baseline collagen secretion, but reduced the IGF-I-stimulated secretion of collagen types I and IV by $77 \pm 11 \%$ and $69 \pm 12 \%$, respectively.

\section{Discussion}

The present studies demonstrate that in nephrotic rats IGF-I is ultrafiltered into proximal tubules in association with IGFBP-2

Table III. Effect of Normal and Nephrotic Rat Proximal Tubular Fluid (PTF) and rhIGF-I on $\left[{ }^{3} H\right]$ Thymidine Incorporation in Mouse Proximal Tubular Cells

\begin{tabular}{cccc}
\hline \multicolumn{1}{c}{ Group } & \multicolumn{2}{c}{ IGF-I-receptor antibody } & Probability \\
\hline$n=7$, cpm $/$ well & - & + & $P(-$ vs + Antibody $)$ \\
Normal PTF $(1: 10)$ & $1,359 \pm 83$ & $1,139 \pm 110$ & ns \\
$\quad($ control $)$ & & & \\
Nephrotic PTF $(1: 10)$ & $2,057 \pm 207$ & $1,633 \pm 131$ & $P=0.0692$ \\
$P$ vs control & $<0.05$ & ns & \\
rhIGF-I, 200 pM & $2,406 \pm 281$ & $1,496 \pm 85$ & $P<0.05$ \\
$P$ vs control & $<0.05$ & ns & \\
rhIGF-I, 1 nM & $6,987 \pm 472$ & $2,701 \pm 358$ & $P<0.05$ \\
$P$ vs control & $<0.05$ & $<0.05$ & \\
& & & \\
\hline
\end{tabular}



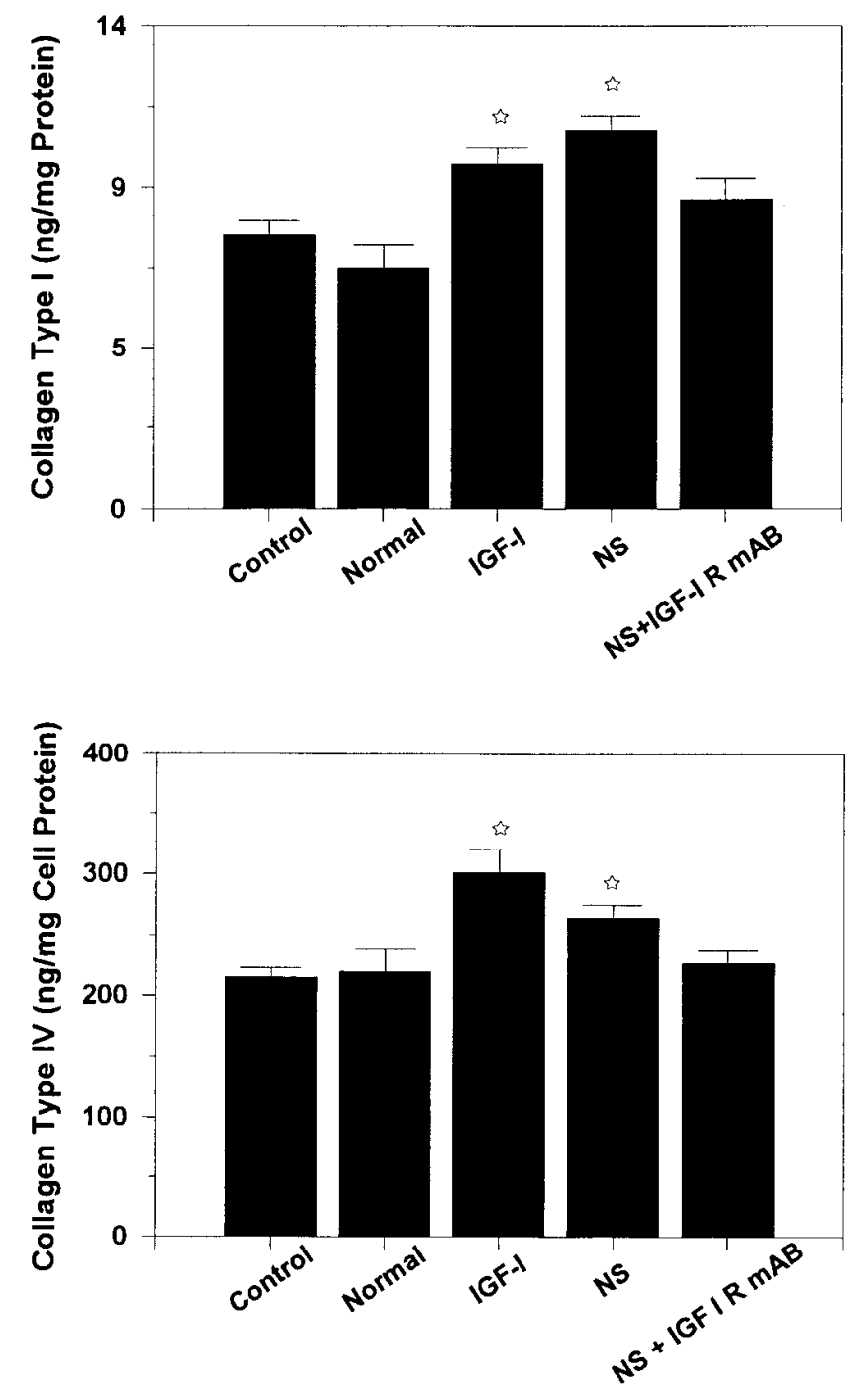

Figure 6. Effect of rhIGF-I ( $2 \mathrm{nM})$ and normal or nephrotic $(N S)$ rat urine extract (1:5) in the absence or presence of IGF-I-receptor neutralizing antibody (IGF-I R $m A b$ ) on secreted collagen type I (top) and type IV (bottom). Cells were incubated for $60 \mathrm{~h}$. Media were concentrated tenfold and then analyzed by ELISA. Data are mean $\pm \operatorname{SEM}\left(n=12\right.$ per group). ${ }^{*} P<0.05$ vs control.

and that IGF-I is bioactive in tubule fluid. The fractional renal clearance (fractional excretion) of IGF-I was more than one order of magnitude lower than the single nephron fractional clearance (sieving coefficient) of IGF-I. This finding suggests that only a small percentage of the ultrafiltered IGF-I undergoes urinary excretion. Most of the IGF-I that is ultrafiltered into proximal tubules appears to be either bound and/or degraded somewhere in the nephron, and measurements in urine underestimate the rate of glomerular ultrafiltration of IGF-I.

Increased urinary excretion of IGF-I and IGFBPs in the nephrotic syndrome have been described previously by this and other laboratories (4-6). These latter studies also demonstrated urinary excretion of IGFBP-3 in the nephrotic syndrome. The present finding that IGFBP-3 does not seem to be present in proximal tubular fluid in nephrotic rats may suggest that this binding protein is secreted in the distal nephron, but this has not yet been proven directly.
Two mechanisms contribute to the glomerular ultrafiltration of IGF-I in addition to the defect in the glomerular ultrafiltration barrier. First, IGFBP-2-containing protein complexes are relatively small $(\sim 45 \mathrm{kD})$ and are therefore more likely to undergo glomerular ultrafiltration in the nephrotic syndrome compared to the large $(\sim 150 \mathrm{kD})$ complex. This is further corroborated by the finding that the single nephron clearance of IGF-I was about threefold greater than the single nephron clearance of albumin $(68 \mathrm{kD})$. This suggests that the molecular mass at which IGF-I undergoes glomerular ultrafiltration is less than that of albumin. The ratio of the single nephron clearances of IGF-I and albumin would be expected to be $<1.0$, if the ultrafiltration of IGF-I would primarily occur as the $150 \mathrm{kD}$ molecular complex. Second, as was demonstrated previously from this laboratory, serum IGFBP-2 is elevated severalfold in the nephrotic syndrome as a result of increased synthesis of this binding protein in the liver (4). Moreover, serum IGFBP-3, which normally carries most of the circulating IGF-I, is reduced in the nephrotic syndrome $(4,27)$.

Although the present experimental findings suggest that IGF-I undergoes glomerular ultrafiltration together with IGFBP-2 as a $\sim 45 \mathrm{kD}$ molecular complex, the peptide may not remain in this complex. The tubular fluid composition changes with downstream flow and the $\mathrm{pH}$ decreases. This may favor dissociation of the peptide from the binding protein.

In nephrotic rats, IGF-I is present in glomerular ultrafiltrate at concentrations that are biologically significant because IGF-I activates IGF-I receptors in proximal tubular cells and may activate IGF-I receptors in the apical cell membrane of renal tubules in vivo. The in vitro studies in cultured mouse proximal tubular cells that express IGF-I receptors (13) show that proximal tubular fluid obtained from nephrotic rats increases the receptor $\beta$-subunit autophosphorylation (Fig. 4). This finding also indicates that IGF-I in tubule fluid remains bioactive.

There are species differences within several experiments in the present studies. These include the study of effects of rat IGF-I and rhIGF-I on biologic events in mouse proximal tubular cells. Sequence and structure of human, rat, and mouse IGF-I, IGF-I receptors, and IGFBPs are similar, and binding of IGF-I to IGF-I receptors and IGFBPs have been shown to occur across species boundaries $(13,14,28)$. There may be some species-dependent differences in the binding affinity of IGF-I to the receptor and to IGFBPs that are currently unknown and were not examined in the present study.

IGFBPs in general, and IGFBP-2 specifically, have been shown to inhibit as well as enhance actions of IGF-I (7, 29-33). In the present in vitro studies, rhIGFBP-2 at fivefold molar excess only modestly inhibits the activation of IGF-I receptors by the ligand in cultured proximal tubule cells (Fig. 4). Several factors may contribute to this modest inhibitory action of IGFBP-2 in this experiment. Compared to other IGFBPs, IGFBP-2 has a lower affinity for IGF-I compared to IGF-II (34). The excess IGFBP-2 concentration was chosen to allow for the detection of even modest inhibition of IGF-I by this binding protein. Although the actual levels of IGFBP-2 in tubule fluid were not measured quantitatively, it is unlikely that the levels were of great molar excess compared to the IGF-I concentration. The results of other experiments within the present studies (Figs. 5 and 6) also indicate that tubule fluid IGF-I is bioactive despite the presence of IGFBP-2.

IGF-I is a modest mitogen and is known to increase the $\left[{ }^{3} \mathrm{H}\right]$ thymidine uptake in vitro in cultured tubular cells (10) and 
in vivo in proximal tubules in rats (11). Fig. 5 indicates that tubule fluid from nephrotic rats raises the $\left[{ }^{3} \mathrm{H}\right]$ thymidine uptake in cultured proximal tubule cells through IGF-I receptor mechanisms, since the effect tends to be ameliorated with neutralizing IGF-I receptor antibodies. The bioactivity towards $\left[{ }^{3} \mathrm{H}\right]$ thymidine uptake that is not inhibited by the neutralizing receptor antibody results from either incomplete inhibition of the receptors and/or the presence of other mitogens in proximal tubular fluid. Jones et al. demonstrated tubule epithelial cell proliferation in vivo in rats with the experimental nephrotic syndrome (35). The findings in the present study suggest that ultrafiltered IGF-I contributes to this process.

Glomerular diseases that cause heavy proteinuria are often associated with progressive tubulo-interstitial injury, which appears to define the degree and rate of progression of renal failure (36-46). This can be demonstrated in human renal disease as well as in experimental rat models of the nephrotic syndrome (3, 36-46). Furthermore, clinical trials have shown that the degree of proteinuria correlates positively with the rate of progression of renal failure $(1,2,47)$. Rats with adriamycininduced experimental glomerulopathy develop chronic renal failure and tubulo-interstitial scarring in association with prolonged, severe proteinuria (3). Thus, there is clinical and experimental evidence to suggest a connection between heavy proteinuria, interstitial fibrosis, and the progression of renal failure.

Experimental evidence indicates that tubulo-interstitial damage may not result from ultrafiltered albumin per se, but may rather be induced by compounds that are associated with filtered plasma proteins. Thomas and associates have suggested that fatty acids that are carried on ultrafiltered albumin may contribute to the tubulo-interstitial injury in the nephrotic syndrome, but not fatty acid-free albumin $(48,49)$. The present studies suggest that IGF-I may also contribute to this sequelae. IGF-I is a growth factor peptide with a variety of biologic actions that include the induction of extracellular matrix protein synthesis such as collagen type I and IV (8). Under normal conditions, serum IGF-I is largely excluded from glomerular ultrafiltration due to its protein binding, but not in the nephrotic syndrome. The present studies demonstrate that rhIGF-I, as well as the urinary extracts from nephrotic rats, increase the secretion of collagen type I and IV in cultured proximal tubular cells. This extract may also contain growth factor peptides and bioactive compounds other than IGF-I that could raise the collagen synthesis. However, the finding that incubation of the cells with the urine extract in the presence of neutralizing IGF-I-receptor antibodies reduces the extract-induced rise in collagen secretion suggests that the IGF-I content contributes to the increased collagen formation (Fig. 6). Hence, IGF-I that reaches tubular cells by means of glomerular ultrafiltration may contribute to the extracellular matrix accumulation in chronic nephrotic diseases either directly or indirectly or both. Ziyadeh et al. recently demonstrated that in cultured proximal tubular cells (the same cell line as used in the present studies), IGF-I increases the expression of TGF- $\beta$ type II receptors without changing the TGF- $\beta$ levels (28). Indeed, in rats with the adriamycin-induced nephrotic syndrome, the renal expression of TGF- $\beta$ type II receptors is substantially increased (50). The TGF- $\beta$ system, in turn, is known to contribute markedly to the extracellular matrix accumulation in a variety of in vivo and in vitro renal disease models $(35,51)$. Hence, tubular fluid IGF-I may also act through this latter mechanism.
In summary, the in vivo and in vitro studies demonstrate that IGF-I is present in tubule fluid in nephrotic rats and that the peptide is bioactive. IGF-I can transmit metabolic activity through apical tubule IGF-I-receptors. Tubular-fluid IGF-I may raise the increase in collagen secretion by tubular cells, which may contribute to interstitial extracellular matrix accumulation and scar formation. Thus, the glomerular ultrafiltration of IGF-I in the nephrotic syndrome may contribute to the tubulo-interstitial fibrosis that facilitates progressive renal failure in chronic nephrotic glomerular diseases.

\section{Acknowledgments}

The author would like to thank Ilyse Vanderah, M.S., who assisted skillfully in some of the experiments.

Parts of these studies were supported by a grant from the American Heart Association, National Center (Dallas, TX) and with support from the Harbor-UCLA Research \& Education Institute (Torrance, $\mathrm{CA}$ ).

\section{References}

1. Klahr, S., A.S. Levey, G.J. Beck, A.W. Caggiula, L. Hunsicker, J.W. Kusek, and G. Striker. 1994. The effects of dietary protein restriction and blood-pressure control on the progression of chronic renal disease. Modification of Diet in Renal Disease Study Group. N. Engl. J. Med. 330:877-884.

2. Jackle, I., W. Gunther, H. von Gise, J.M. Alt, A. Bohle, and H. Stolte. 1988. Kidney function and protein excretion in relation to pathomorphology of glomerular diseases. Contrib. Nephrol. 68:128-135.

3. Bertani, T., F. Cutillo, C. Zoja, M. Broggini, and G. Remuzzi. 1986. Tubulo-interstitial lesions mediate renal damage in adriamycin glomerulopathy. Kidney Int. 30:488-496.

4. Hirschberg, R., and G.A. Kaysen. 1995. Insulin-like growth factor I and its binding proteins in the experimental nephrotic syndrome. Endocrinology. 136:1565-1571.

5. Gargosky, S.E., T. Hasegawa, P. Tapanainen, M. MacGillivray, Y. Hasegawa, and R.G. Rosenfeld. 1993. Urinary insulin-like growth factors (IGF) and IGF-binding proteins in normal subjects, growth hormone deficiency, and renal disease. J. Clin. Endocrinol. \& Metab. 76:1631-1637.

6. Garin, E., M. Grant, and J. Silverstein. 1989. Insulin-like growth factors in patients with active nephrotic syndrome. Am. J. Dis. Child. 143:865-867.

7. Jones, J.I., and D.R. Clemmons. 1995. Insulin-like growth factors and their binding proteins: biological actions. Endocr. Rev. 16:3-34.

8. Feld, S., R. Hirschberg, A. Artishevsky, C. Nast, and S. Adler. 1995. Insulin-like growth factor I induces mesangial proliferation and increases mRNA and secretion of collagen. Kidney Int. 48:45-51.

9. Haverty, T.P., C.J. Kelly, W.H. Hines, P.S. Amenta, M. Watanabe, R.A. Harper, N.A. Kefalides, and E.G. Neilson. 1988. Characterization of a renal tubular epithelial cell line which secretes the autologous target antigen of autoimmune experimental interstitial nephritis. J. Cell Biol. 107:1359-1368.

10. Humes, H.D., T.F. Beals, D.A. Cieslinski, I.O. Sanchez, and T.P. Page. 1991. Effects of transforming growth factor-beta, transforming growth factoralpha, and other growth factors on renal proximal tubule cells. Lab. Invest. 64: 538-545.

11. Ding, H., J.D. Kopple, A. Cohen, and R. Hirschberg. 1993. Recombinant human insulin-like growth factor-I accelerates recovery and reduces catabolism in rats with ischemic acute renal failure. J. Clin. Invest. 91:2281-2287.

12. Hammerman, M.R., and S. Rogers. 1987. Distribution of IGF receptors in the plasma membrane of proximal tubular cells. Am. J. Physiol. 253:841-847.

13. Hirschberg, R., H. Ding, and C. Wanner. 1995. Effects of insulin-like growth factor I on phosphate transport in cultured proximal tubule cells. J. Lab. Clin. Med. 126:428-434.

14. Quigley, R., and M. Baum. 1991. Effects of growth hormone and insulin-like growth factor I on rabbit proximal convoluted tubule transport. J. Clin. Invest. 88:368-374.

15. Baxter, R., and J. Martin. 1989. Structure of the Mr 140,000 growth hormone-dependent insulin-like growth factor binding protein complex: determination by reconstitution and affinity-labeling. Proc. Natl. Acad. Sci. USA. 86: 6898-6902.

16. Holly, J. 1993. Insulin-like growth factor binding proteins in diabetic and non-diabetic states. In Growth hormone and insulin-like growth factor I in human and experimental diabetes. A. Flyvbjerg, H. Orskov, and K. Alberti, editors. John Wiley \& Sons Inc., Chichester, UK. 47-76.

17. Frystyk, J., C. Skjaerbaek, B. Dinesen, and H. Orskov. 1994. Free insulin like growth factor (IGF-I and IGF-II) in human serum. FEBS Lett. 348:185-191. 
18. Remuzzi, A., R. Pergolizzi, M.S. Mauer, and T. Bertani. 1990. Threedimensional morphometric analysis of segmental glomerulosclerosis in the rat. Kidney Int. 38:851-856.

19. Hirschberg, R., J.D. Kopple, R.C. Blantz, and B.J. Tucker. 1991. Effects of recombinant human insulin-like growth factor I on glomerular dynamics in the rat. J. Clin. Invest. 87:1200-1206.

20. Hirschberg, R., and J.D. Kopple. 1992. The growth hormone-insulinlike growth factor I axis and renal glomerular function. J. Am. Soc. Nephrol. 2: 1417-1422.

21. Hirschberg, R. 1993. Effects of growth hormone and IGF-I on glomerular ultrafiltration in growth hormone-deficient rats. Regul. Pept. 48:241-250.

22. Hirschberg, R., G. Brunori, J.D. Kopple, and H.P. Guler. 1993. Effects of insulin-like growth factor I on renal function in normal men. Kidney Int. 43: 387-397.

23. Furlanetto, R.W., L.E. Underwood, J.J. Van Wyk, and D.E. AJ. 1977. Estimation of somatomedin-C levels in normals and patients with pituitary disease by radioimmunoassay. J. Clin. Invest. 60:648-657.

24. Hirschberg, R., and J.D. Kopple. 1991. Response of insulin-like growth factor I and renal hemodynamics to a high- and low-protein diet in the rat. $J$. Am. Soc. Nephrol. 1:1034-1040.

25. Hossenlopp, P., D. Seurin, B. Segovia-Quinson, S. Hardouin, and M. Binoux. 1986. Analysis of serum insulin-like growth factor binding proteins using western blotting: use of the method for titration of the binding proteins and competitive binding studies. Anal. Biochem. 154:138-143.

26. Hossenlopp, P., B. Segovia, C. Lassarre, M. Roghani, M. Bredon, and M. Binoux. 1990. Evidence of enzymatic degradation of insulin-like growth factor-binding proteins in the $150 \mathrm{~K}$ complex during pregnancy. J. Clin. Endocrinol. \& Metab. 71:797-805.

27. Thabet, M.A., A. Challa, W. Chan, F. Liu, R.L. Hintz, and J.C. Chan. 1994. Insulin-like growth factor and growth hormone receptor in nephrotic rats. Am. J. Physiol. 266:102-106.

28. Ziyadeh, F., Y. Jin, J. Guo, M. Ericksen, and K. Sharma. 1995. Up-regulation of type II TGF-B receptor mRNA by IGF-1 in proximal tubular cells: Role in diabetic renal hypertrophy. J. Am. Soc. Nephrol. 6:1053. (Abstr.)

29. Baxter, R.C. 1991. Insulin-like growth factor (IGF) binding proteins: the role of serum IGFBPs in regulating IGF availability. Acta Paediatr. Scand. Suppl. 372:107-114; Discussion 115.

30. Bourner, M., W. Busby, N. Seigel, G. Krivi, R. McCusker, and D. Clemmons. 1992. Cloning and sequence determination of bovine insulin-like growth factor binding protein-2 (IGFBP-2): comparison of its structural and functional properties with IGFBP-1. J. Cell Biochem. 48:215-226.

31. Reeve, J., J. Schwander, and N. Bleehen. 1993. IGFBP-2: an important regulator of insulin like growth factor action in human lung tumors. Growth Regulation. 3:82-84.

32. Ross, G., G. Francis, L. Szabo, J. Wallace, and F. Ballard. 1989. Insulinlike growth factor (IGF)-binding proteins inhibit the biological activities of IGF-I and IGF-2 but not des-(1-3)-IGF-I. Biochem. J. 258:267-272.

33. Feyen, J., D. Evans, C. Binkert, G. Heinrich, S. Geisse, and H. Koeher. 1991. Recombinant human CYS 281 insulin like growth factor binding protein-2 inhibits both basal and insulin like growth factor I stimulated proliferation and collagen synthesis in fetal rat calvaria. J. Biol. Chem. 266:19469-19474.

34. Bach, L.A., S. Hsieh, K. Sakano, H. Fujiwara, J.F. Perdue, and M.M. Rechler. 1993. Binding of mutants of human insulin-like growth factor II to insulin-like growth factor binding proteins 1-6. J. Biol. Chem. 268:9246-9254.

35. Jones, C.L., S. Buch, M. Post, L. McCulloch, E. Liu, and A.A. Eddy. 1992. Renal extracellular matrix accumulation in acute puromycin aminonucleoside nephrosis in rats. Am. J. Pathol. 141:1381-1396.

36. Bader, R., H. Bader, K. E. Grund, S. Mackensen-Haen, H. Christ, and
A. Bohle. 1980. Structure and function of the kidney in diabetic glomerulosclerosis. Correlations between morphological and functional parameters. Pathol. Res. Pract. 167:204-216.

37. Mackensen-Haen, S., R. Bader, K.E. Grund, and A. Bohle. 1981. Correlations between renal cortical interstitial fibrosis, atrophy of the proximal tubules and impairment of the glomerular filtration rate. Clin. Nephrol. 15:167171.

38. Haen, M., S. Mackensen-Haen, T. Klingebiel, B. Stark-Jakob, H. Christ, and A. Bohle. 1985. Creatinine clearance and renal interstitium in diffuse endocapillary proliferative glomerulonephritis. Pathol. Res. Pract. 179:462-468.

39. Schmitt, H., V. Cavalcanti de Oliveira, and A. Bohle. 1987. Tubulointerstitial alterations in type I membranoproliferative glomerulonephritis. An investigation of 259 cases. Pathol. Res. Pract. 182:6-10.

40. Bohle, A., S. Mackensen-Haen, and H. von Gise. 1987. Significance of tubulointerstitial changes in the renal cortex for the excretory function and concentration ability of the kidney: a morphometric contribution. Am. J. Nephrol. 7:421-433.

41. Mackensen-Haen, S., R. Eissele, and A. Bohle. 1988. Contribution on the correlation between morphometric parameters gained from the renal cortex and renal function in IgA nephritis. Lab. Invest. 59:239-244.

42. Wehrmann, M., A. Bohle, O. Bogenschutz, R. Eissele, A. Freislederer, C. Ohlschlegel, G. Schumm, C. Batz, and H.V. Gartner. 1989. Long-term prognosis of chronic idiopathic membranous glomerulonephritis. An analysis of 334 cases with particular regard to tubulo-interstitial changes. Clin. Nephrol. 31:6776.

43. Wehrmann, M., A. Bohle, H. Held, G. Schumm, H. Kendziorra, and H. Pressler. 1990. Long-term prognosis of focal sclerosing glomerulonephritis. An analysis of 250 cases with particular regard to tubulointerstitial changes. Clin. Nephrol. 33:115-122.

44. Bohle, A., M. Wehrmann, O. Bogenschutz, C. Batz, C.A. Muller, and G.A. Muller. 1991. The pathogenesis of chronic renal failure in diabetic nephropathy. Investigation of 488 cases of diabetic glomerulosclerosis. Pathol. Res. Pract. 187:251-259.

45. Mackensen-Haen, S., A. Bohle, J. Christensen, M. Wehrmann, H. Kendziorra, and F. Kokot. 1992. The consequences for renal function of widening of the interstitium and changes in the tubular epithelium of the renal cortex and outer medulla in various renal diseases. Clin. Nephrol. 37:70-77.

46. Bohle, A., M. Wehrmann, O. Bogenschutz, C. Batz, W. Vogl, H. Schmitt, C.A. Muller, and G.A. Muller. 1992. The long-term prognosis of the primary glomerulonephritides. A morphological and clinical analysis of 1747 cases. Pathol. Res. Pract. 188:908-924.

47. Milewski, C., M. Konig, H. von Gise, and A. Bohle. 1983. Clinical and morphological aspects of nephrotic syndrome in perimembranous, focally sclerosing and membrano-proliferative glomerulonephritis. Klin. Wochenschr. 61: 493-497.

48. Thomas, M.E., A.R. Morrison, and G.F. Schreiner. 1995. Metabolic effects of fatty acid-bearing albumin on a proximal tubule cell line. Am. J. Physiol. 268:1177-1184.

49. Thomas, M.E., and G.F. Schreiner. 1993. Contribution of proteinuria to progressive renal injury: consequences of tubular uptake of fatty acid bearing albumin. Am. J. Nephrol. 13:385-398.

50. Tamaki, K., S. Okuda, T. Ando, T. Iwamoto, M. Nakayama, and M. Fujishima. 1994. TGF-beta 1 in glomerulosclerosis and interstitial fibrosis of adriamycin nephropathy. Kidney Int. 45:5255-5236.

51. Creely, J.J., S.J. DiMari, A.M. Howe, and M.A. Haralson. 1992. Effects of transforming growth factor-beta on collagen synthesis by normal rat kidney epithelial cells. Am. J. Pathol. 140:45-55. 